\title{
PLATARAN REMPUG RAWA BELONG
}

\author{
Christabella Nadia Angela ${ }^{1)}$, Franky Liauw ${ }^{2)}$ \\ 1)Program Studi S1 Arsitektur, Fakultas Teknik, Universitas Tarumanagara, \\ christabella.bellaaa@gmail.com \\ 2) Program Studi S1 Arsitektur, Fakultas Teknik, Universitas Tarumanagara, frankyl@ft.untar.ac.id
}

\begin{abstract}
Abstrak
Rawa Belong merupakan salah satu kelurahan ditengah kepadatan kota Jakarta. Suatu kelurahan yang diisi oleh interaksi social yang memberi kehidupan bagi kota. Sebuah wadah dan ruang public dimana setiap orang dapat melakukan aktivitas rekreasi dan mengekspresikan dirinya secara bebas. Dengan latar belakang sejarah budaya betawi dan juga tanaman hias, daerah Rawa Belong dipandang sebagai sesuatu yang khas dan istimewa. Berbagai macam komunitas dengan berbagai latar belakang ada di dalamnya, kebebasan yang seharusnya ada dalam sebuah ruang public tidak terlihat di daerah ini karena begitu padatnya satu dengan yang lainnya baik dalam interaksi antar manusia maupun interaksi dengan lingkungannya. Proyek ini didasari menggunakan metode "Everyday Urbanism" untuk melakukan pengamatan dan analisa terhadap kehidupan di Rawa Belong. Kemudian proyek ini diciptakan untuk menjawab kebutuhan wadah rekreasi yang ada, dimana wadah ini akan dilihat sebagai sebuah koneksi antar ruang-ruang yang hilang dan menggabungkan semua komunitas dan masyarakat yang seharusnya ada dalam sebuah ruang terbuka.
\end{abstract}

Kata kunci: budaya; interaksi social; komunitas; ruang terbuka; tanaman hias

\begin{abstract}
Rawa Belong is one of the village in Jakarta's density. Then this village was filled by social interactions that give a life to the city. A public space that everyone can relax and leisure also express themselves freely. With a cultural background and plants, Rawa Belong began to be seen as something special. Various communities and people with a different background are in it. Freedom that should be in a public space is not happen here, because of the density both in the interaction between people and their environment. This project is based on "Everyday Urbanism" method to observe and analysis the urban life in Rawa Belong. Then this project was created to resolve what people in Rawa Belong needs such as a place to recreation and leisure where will be seen as a connection between lost spaces also to create a space that combine all the people and community that should be in a public space.
\end{abstract}

Keywords: community; cultural; plants; public space; social interactio

\section{PENDAHULUAN}

\section{Latar Belakang}

Manusia pada dasarnya adalah makhluk social yang tidak dapat melakukan segala aktivitasnya sendiri. Setiap individu memiliki pekerjaan sendiri yang dipilihnya untuk mendukung kehidupannya, dan kehidupan orang lain di sekitarnya. Kegiatankegiatan tersebut sangat beragam; dan bila didukung dengan kondisi geografis setempat yang memungkinkan mobilitas secara lebih baik, akan timbul suatu kepadatan aktivitas. Kepadatan aktvitas di suatu tempat akan menarik banyak orang-orang dari daerah sekitar untuk datang ke tempat tersebut, dan menyebabkan kepadatan penduduk. Pola tersebut berulang, dan merupakan pola umum 
terbentuknya sebuah kota. Sehingga, sebuah kota tidak akan lepas dari kepadatan aktvitas dan kepadatan penduduk. Kawasan Palmerah merupakan kawasan di wilayah Jakarta barat yang heterogen dimana terdapat padatnya perpindahan masyarakat dari dalam dan luar kawasan, juga terdapat banyak fasilitas seperti stasiun, pasar tradisional, universitas, sekolah tinggi, perkantoran, perumahan dan pertokoan yang membuat daerah Palmerah ini ramai dan padat. Hal ini mempengaruhi karakteristik tempat-tempat yang dapat menjadi third place bagi mereka khususnya para pedagang pasar tradisional yang merupakan masyarakat dengan tingkat ekonomi yang menengah ke bawah tidak bisa menikmati fasilitas rekreasi yang berbayar karena minimnya uang yang bisa dihamburkan untuk berekreasi. Kelurahan yang dipilih adalah Rawa Belong, Kurangnya fasilitas rekreasi yang tidak berbayar di Rawa Belong ini juga menjadi tujuan utama dari program yang akan dibuat supaya bisa memfasilitasi masyarakat yang menengah ke bawah untuk bisa menyediakan tempat melepas stress dan penat diluar rutinitas keseharian. Juga menyediakan wadah pembelajaran bagi masyarakat yang pengangguran.

Kehidupan berkota dipenuhi persaingan ekonomi yang tinggi, Setiadi (2012) menyatakan bahwa hidup di perkotaan mampu menawarkan berbagai kemudahan dan mimpi-mimpi sukses, sehingga peristiwa urbanisasi tidak dapat dihindari. Untuk memenuhi kebutuhan dan keinginan, setiap warga akan bersaing untuk bekerja lebih giat. Rutinitas pun menjadi tidak terelakkan. Kegiatan bekerja dan pulang ke rumah terus menerus berulang dan memicu kebosanan dan tekanan mental(stress).kondisi stress ini dapat memicu perubahan fisik dan perlilaku psikologis dari setiap individu yang mengalaminya. Kekurangan ruang dan perasaan sesak menjadi masalah utama terhadap ruang personal setiap individu. Kegiatan-kegiatan yang beragam di suaru kawasan terkadang dianggap hanya sebagai pengganggu dan penambah penat, karena banyak orang bahkan sudah muak dengan aktivitas-aktivitas yang mereka telah jalani di kantor dan rumah. Sehingga butuh suatu tempat ketiga, tempat ketiga(third place) adalah sebuah tempat dimana seseorang dapapt melepaskan stress mereka melalui aktivitasaktivitas yang tersedia. Setiap individu memiliki tempat ketiga yang berbeda.

\section{Rumusan Permasalahan}

Rumusan masalah yang diangkat oleh penulis adalah mengadakan wadah rekreasi dan relaksasi bagi para pedagang pasar tradisional dan juga masyrakat lain yang tidak memandang umur, ras, agama, dan lainnya. Proyek ini juga menjawab permasalahan pengolahan sampah dengan cara kreatif yang memberikan output berupa produk yang bisa dijadikan sumber ekonomi bagi komunitas, pedagang maupun masyarakat, sekaligus menjadikan proyek ini tempat ketiga bagi masyarakat dengan mengedukasi dan menyediakan wadah untuk masyarakat saling berinteraksi dan bertukar pikiran.

\section{Tujuan}

Setiap proyek yang terbangun memiliki maksud dan tujuan, adapun maksud dari proyek Plataran Rempug Rawa Belong ini antara lain:

a. Menjadi wadah atau tempat bersosialisasi dan interaksi masyarakat dan komunitas sekitar.

b. Menjadi wadah belajar dan rekreasi masyarakat sekitar

c. Menghadirkan kegiatan dan aktivitas yang dapat merelaksasi pengunjung.

d. Membangun nilai kebersamaan antar semua golongan masyarakat.

e. Meningkatkan rasa cinta lingkungan.

f. Menjadikan proyek ini nodes Rawa Belong.

g. Melibatkan semua kalangan masyarakat untuk bisa berpartisipasi di dalam kegiatan yang ada. 


\section{KAJIAN LITERATUR}

Keberadaan third place ditujukan sebagai fungsi tersier (pelengkap) dalam aktivitas sehari hari, Menurut Oldenburg (1989) karakteristik Third Place meliputi, On Neutral Ground, The Third Place as Leveler, Conversation is the Main Activity, Accessibility and Accommodation, The Regulars, A Low Profile, The Mood is Playful, A Home Away from Home. Beberapa poin penting yang harus ada didalam third place. terdapat beberapa poin penting yang harus ada didalam third place, yaitu:

a. Neutral ground: Pengunjung bebas mengakses tempat tanpa hambatan apapun

b. Leveler (a leveling place): Tidak terikat dengan status sosial.

c. Conversation is the main activity: Pembicaraan yang menyenangkan antar individu

d. Accessibility and accommodation: Dapat memenuhi kebutuhan penggunanya

e. The regulars: Pengunjung lama dapat menarik pengunjung baru

f. A low profile: Tidak mahal dan sederhana

g. The mood is playful: Memiliki sifat yang menyenangkan

h. A home away from home: Spiritual regeneration

Third place memiliki kekhasan yang berbeda dengan third place di tempat lain, termasuk didalamnya adalah ruang dan program yang terjadi di dalam third place. Third place merupakan bagian dari komunitas, karena itu aksebilitas menjadi hal penting. Aksebilitas sangat diperlukan, karena itu posisi terhadap komunitas menjadi perlu, bahkan terkadang third place memiliki posisi penting dari kantor pemerintahan. third place sebagai tempat dimana masyarakat berkumpul, dan memiliki status yang sama sehingga third place menjadi tempat netral, dan sederhana. Dalam buku Attention and Self-Regulation: A Contol-Theory Approach to Human Behavior yang ditulis oleh Charver Charles menjelaskan bagaimana memahami kebutuhan manusia dengan pendekatan yang berbeda - beda. Control (kendali) merupakan teori yang berujung kepada perintah untuk mengendalikan suatu pikiran dalam alam bawah sadar manusia. Kendali yang merupakan pusat untuk melakukan segala rangkaian aktivitas, dalam kategori ini pola kendali tiap manusia memiliki pola yang beragam untuk dapat dimengerti karena faktor psikologi juga mempengaruhinya.Ketertarikan manusia didasari oleh rasa ingin tahu yang tinggi, hingga menimbulkan sebuah gagasan dalam pikirannya untuk menelusuri lebih jauh. Sifat tersebut dapat menimbulkan efek yang baik dan juga buruk, tergantung kepada sifat dan karakter manusia.

\section{METODE}

\section{Metode Riset}

Everyday Urbanism

Metode everyday urbanism merupakan konsep yang diperkenalkan oleh Margaret Crawford, John Chase dan John Kaliski pada tahun 1999. Everyday Urbanism adalah metode yang menjelaskan tentang interaksi sehari-hari di dalam ruang kota yang sangan kompleks. Mengidentifikasi sebuah urbanisasi, membutuhkan sudut padat yang luas dengan ilmu yang disiplin. Kehidupan di ruang kota mengandung banyak arti yang memiliki nilai kontradiktif, baik secara intelektual, ekonomi, sosial, eksperimental dan politik.

\section{Survey Lapangan}

Tinjauan langsung atau survey lapangan pada kawasan Rawa Belong untuk merasakan dan melihat keadaan dan situasi secara langsung dan bisa mengetahui secara nyata fasilitas yang ada dan fasilitas yang kurang serta mendokumentasikan kegiatan di lapangan. Kelurahan Rawa Belong dikenal pasar tradisional, pasar bunga juga kebudayaan betawi. Di Kelurahan Rawa Belong juga merupakan daerah yang padat cenderung tidak tertata dengan baik, jalan kendaraan juga tidak terlalu besar sehingga hampir setiap hari terjadi kemacetan. 


\section{Partisipatory Action Research}

Metode partisipatoris merupakan cara mengumpulkan data atau informasi dengan melibatkan semua pihak yang relevan dalam mengkaji tindakan di lapangan. Sehingga dengan metode pencarian data ini, diharap bisa membantu memperkuat landasan proyek yang didasari metode everyday urbanism, berikut merupakan cara-cara untuk memperoleh informasi dengan metode partisipatoris, yaitu:

\section{A. Wawancara}

Wawancara adalah teknik pengumpulan data yang dilakukan melalui tatap muka dan tanya jawab langsung antara peneliti dan narasumber.

B. Observasi

Observasi adalah metode pengumpulan data yang rumit karena melibatkan beberapa faktor di dalamnya. Metode pengumpulan data observasi tidak hanya mengukur sikap dari responden, namun juga dapat digunakan untuk merekam berbagai keadaan dan situasi yang terjadi di lapangan. Teknik ini digunakan untuk penelitian yang bertujuan untuk mempelajari tingkah laku manusia, proses kerja dan gejala-gekala kondisi alam yang ada

C. Angket (kuisioner)

Kuisioner merupakan metode pengumpulan data yang dilakukan dengan cara memberi beberapa pertanyaan kepada responden untuk memberikan jawaban. Kuisioner merupakan metode pengumpulan data yang lebih efisien bila peneliti telah mengetahui dengan pasti variabel yang akan diukur dan tahu apa yang diharapkan dari responden.

\section{DISKUSI DAN HASIL}

\section{Ide Perencanaan}

\section{Wadah belajar dan interaksi sosial}

Wadah sosial merupakan area yang bersifat umum bagi setiap masyarakat agar dapat mengaksesnya, kebutuhan wadah sosial juga harus dapat memfasilitasi kegiatan masyarakat secara menyeluruh sesuai dengan kebutuhan penduduk. Hal ini disebabkan oleh kurangnya fasilitas sosial yang mewadahi kegiatan masyarakat, program ini dipilih menjadi program utama karena kurangnya fasilitas sosial seperti, taman kota, pendidikan non-formal, area sosial. Fungsi utama merupakan tempat ketiga, selain itu juga ada fungsi komersial seperti foodcourt sebagai fasilitas pendukung juga dapat menjadi sarana pengenalan budaya lewat kuliner.

\section{Minim Interaksi Masyarakat di Perkotaan}

Masyarakat kota cenderung memiliki berbagai macam kesibukan, seperti bekerja, bersekolah, berkuliah dan masih banyak aktivitas lainnya yang memakan waktu dan dilakukan setiap hari. Pada saat seseorang pulang, orang tersebut akan langsung beristirahat karena aktivitas dan kegiatan yang begitu melelahkan. Alternatif yang diberikan sebagai jembatan antara masyarakat agar dapat berkomunikasi merupakan sebuah ruang interaktif yang dapat menumbuhkan sifat sosial dan kepekaan antara sesama juga ikut berpartisipasi dalam menjaga lingkungan dengan cara mengolah sampah organik dan anorganik. Perkembangan teknologi perlahan - lahan menggantikan kehadiran fisik manusia dengan ada nya sosial media sebagai perangkat untuk berinteraksi antara sesama yang mungkin berada jauh dari lokasi tertentu karena teknologi inilah yang menumbuhkan nilai individualis yang tidak mementingkan sekitar manusia.

\section{Ide Perencanaan}

Ide konsep perencanaan diawali dari melihat potensi dari lokasi kawasan dimana mempunyai latar belakang budaya betawi dan juga tanaman hias yang bisa dijadikan nilai lebih. Aspekaspek tersebut bisa dijadikan pembelajaran soft dan hard skill untuk masyarakat bisa belajar dan berkembang di era modern dengan persaingan ekonomi yang tinggi. Dengan 
perkembangan teknologi modern saat ini banyak kemudahan yang diberikan untuk mencapai tujuan yang diinginkan, selain itu juga bisa mendapat akses berbagai macam informasi sesuai dengan kebutuhannya dan bisa menarik masyarakat lain untuk bisa mengajar dan belajar bagaimana mengolah sampah organik dan anorganik dengan produk hasil akhir yang bisa dijual kembali untuk mendukung ekonomi. Usulan program yang diberikan mengacu pada fenomena yang terjadi pada masyarakat sekitar yaitu kurangnya taman kota dan interaksi antara sesama penduduk yang memunculkan sifat individualis masyarakat. Program yang disajikan merupakan hasil dari analisa, wawancara juga survey tapak studi terpilih

\section{Program Kegiatan}

Wadah belajar dan interaksi sosial sebagai fasilitas rekreasi dan relaksasi di Rawa belong memiliki 4 program yaitu hiburan dan rekreasi, edukasi, kreativitas dan sosialisasi.

Berikut klasifikasi program yang telah ditentukan:

a. Hiburan dan rekreasi

Sebagai wadah dan sarana hiburan bagi masyarakat dengan mengadakan berbagai acara workshop/pameran hasil karya dari masyarakat dan juga beberapa khas budaya betawi.

- Virtual garden, ruang pertunjukkan visual dengan memperlihatkan projeksi taman dan tanaman yang beragam dari Negara-negara lain.

- Amphitheatre, ruang terbuka untuk menjadi wadah pertunjukkan budaya maupun pertunjukkan seni lainnya.

b. Edukasi

Sebagai wdah dan sarana bagi masyarakat terutama generasi muda untuk dapat mengenal, mempelajari dan menerapkan bagaimana cara mejaga lingkungan dengan mendaur ulang sampah. Masyarakat dan komunitas lain juga bisa saling mengajar dan belajar skill baru untuk meningkatkan ekonomi mereka.

- Workshop, area ruang belajar dan mengajar mengolah sampah organic dan anorganik.

- Galeri Kerajinan Tangan, ruang galeri yang memperlihatkan hasil produk akhir workshop dan beberapa khas budaya betawi.

- Hidroponik pavilion, ruang belajar dan mengajar cara bercocok tanam hidroponik.

c. Kreativitas

Sebagai wadah dan sarana bagi para komunitas dan seniman perangkai bunga maupun pengusaha lainnya untuk bisa ikut mengajar dan belajar bagaimana mendaur ulang sampah dengan output yang menarik. Dengan itu juga bisa membantu melepas rasa penat dari rutinitas sehari-hari dengan melakukan aktivitas-aktivitas baru yang tidak pernah terpikirkan.

- Workshop, area ruang belajar dan mengajar mengolah sampah organic dan anorganik.

d. Sosialisasi

Sebagai wadah and sarana bagi masyarakat dan komunitas sekitar untuk bisa bertukar informasi tentang berbagai hal juga meningkatkan interaksi manusia yang selama ini semakin berkurang karena berada di perkotaan yang sibuk dan individual.

- Workshop

- Galeri

- Amphitheatre

- Hidroponik pavilion

- Virtual garden

Semua program di dalam proyek sebagai wadan dan sarana masyarakat untuk bersosialisasi.

\section{Lokasi}

Kawasan yang dipilih adalah Kecamatan Palmerah mempunyai luas wilayah $5,40 \mathrm{Km}^{2}$ dengan batas wilayah kecamatan palmerah bagian Utara berbatasan dengan Kecamatan Grogol Petamburan, pada bagian Timur berbatasan dengan Kecamatan Gambir Jakarta Pusat, pada 
bagian Selatan berbatasan dengan Kecamatan Tanah Abang-Jakarta Pusat dan Kecamatan Kebayoran Lama-Jakarta Selatan dan pada bagian Barat berbatasan dengan Kecamatan Kebayoran Lama-Jakarta Selatan. Kawasan palmerah terkenal dengan pasar tradisional, perkantoran multimedia dan dikelilingi oleh sekolah tinggi dan universitas sehingga kawasan ini mempunyai banyak fasilitas pendukung untuk memenuhi kebutuhan mahasiswa dan pegawai kantor.

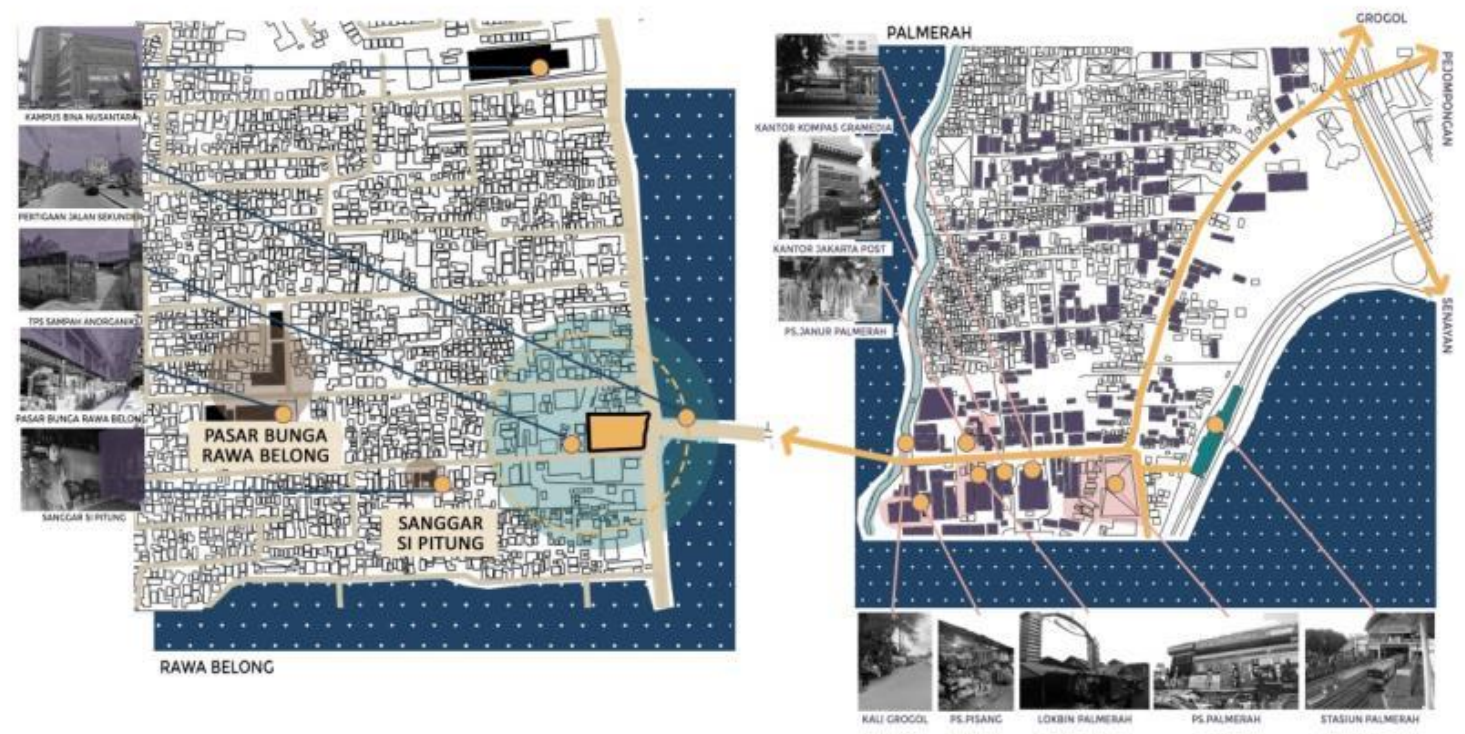

Gambar 1. Analisa Makro kawasan Palmerah dan Rawa Belong Sumber. Dokumen Pribadi,2020

Tapak terpilih berada di dekat ikon dari Kawasan Palmerah, yaitu Pasar bunga Rawa Belong dan juga Sanggar Si Pitung. Tapak berada di pertemuan 3 jalan sekunder yaitu Jl. Rawa Belong, Jl.Tanjung Duren dan Jl.Kebayoran Lama, karena berada di 3 pertemuan jalan ini membuat tapak terpilih memiliki beberapa kelebihan dan kekurangan. Berikut beberapa analisis tapak yang telah dilakukan:
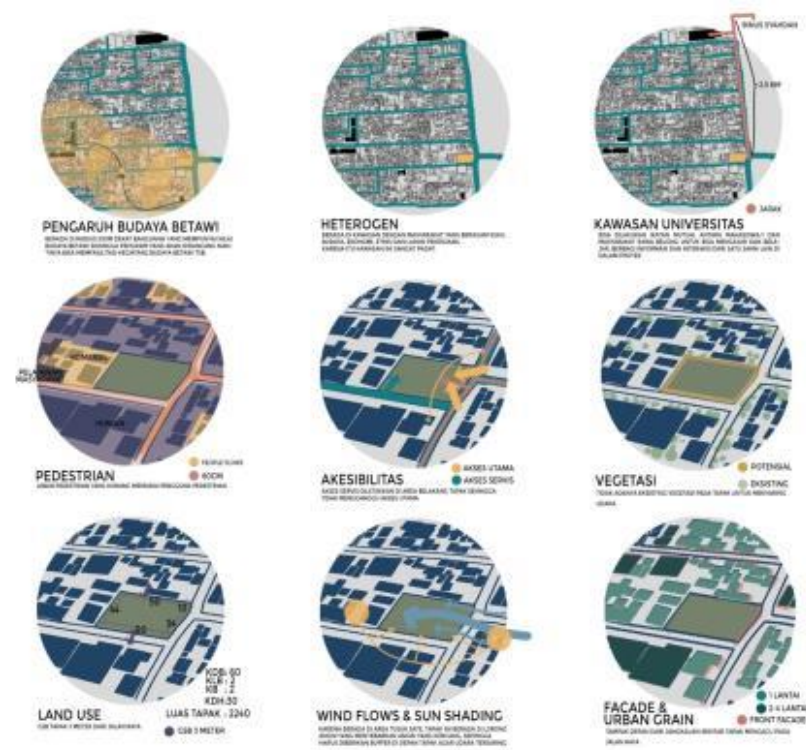

Gambar 2. Analisa tapak

Sumber. Dokumen Pribadi,2020 


\section{POTENSI DAN KEKURANGAN TAPAK}

Kawasan serta tapak yang dipiih memiliki beberapa potensi dan kekurangannya yaitu:

Potensi : tapak berada di kawasan dengan latar belakang budaya, umur dan ekonomi yang berbeda. Berada di jalan sekunder yang mempertemukan 3 kawasan yaitu Palmerah, Tanjung Duren dan Kebayoran Lama, memiliki nilai lokalitas budayanya dan juga merupakan kawasan yang sibuk.

Kekurangan : tidak adanya tempat rekreasi dan relaksasi di daerah Rawa Belong dan tidak adanya area hijau/taman kota.

\section{Ide Desain}

Tahap desain pertama adalah studi ruang pola kegiatan berkumpul masyarakat yang dimulai dai tidak ada interaksi sampai interaksi dari beberapa orang berkumpul yang berakhir pada pola ruang sentralisasi dimana pola ini digunakan sebagai trigger utama dari proyek ini. Pemusatan pada proyek ini juga mengambil konsep dari filosofi rumah kebaya dari budaya Betawi.

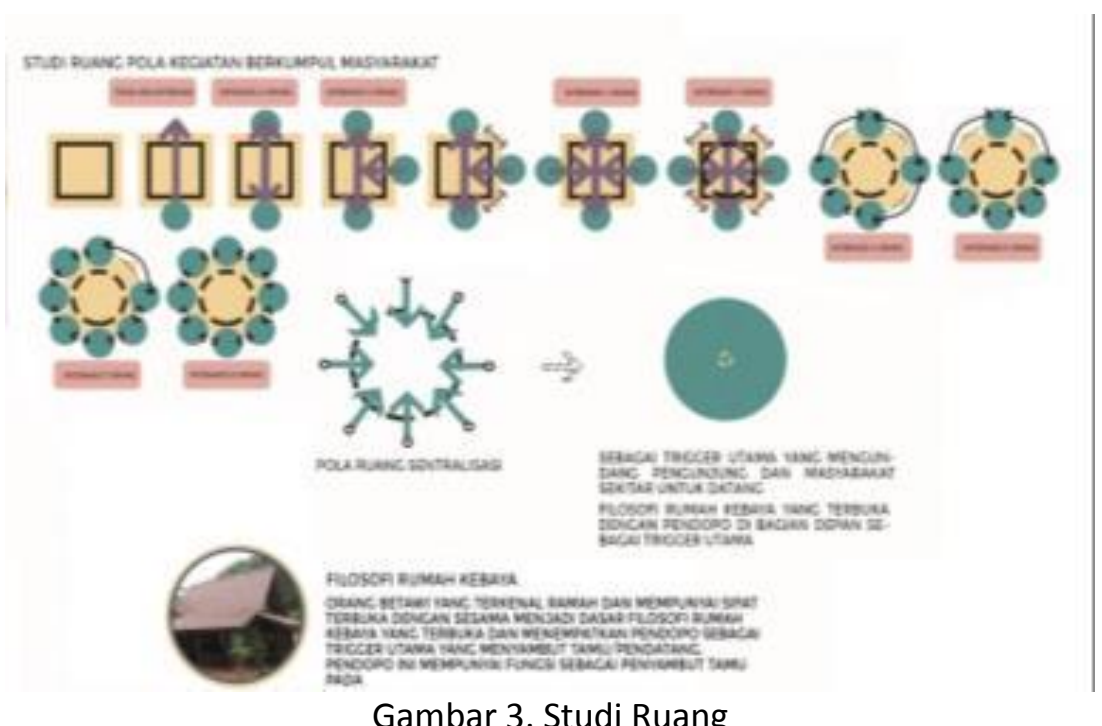

Gambar 3. Studi Ruang

Sumber. Dokumen Pribadi,2020

Setelah menentukkan konsep utama yaitu pola pemusatan sebagai trigger utama dari proyek untuk mengundang masyarakat dan pengunjung untuk datang ke dalam proyek, bentuk bunga anggrek dipilih untuk menjadi konsep bangunan dimana bunga anggrek ini dulunya adalah tanaman hias yang banyak ditanam di daerah Rawa Belong sebelum digusur oleh pemerintah. 


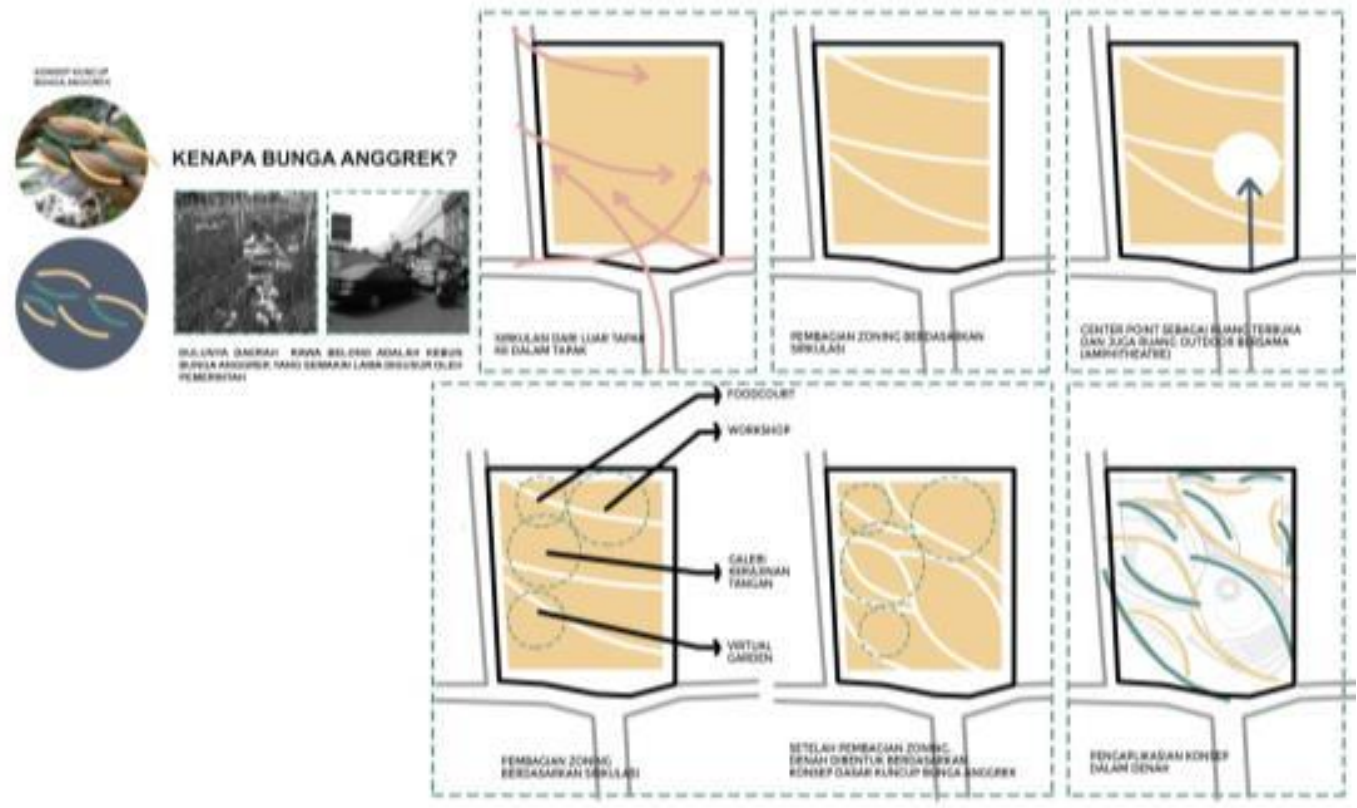

Gambar 4. Proses Perancangan

Sumber. Dokumen Pribadi,2020

\section{Konsep Perancangan}

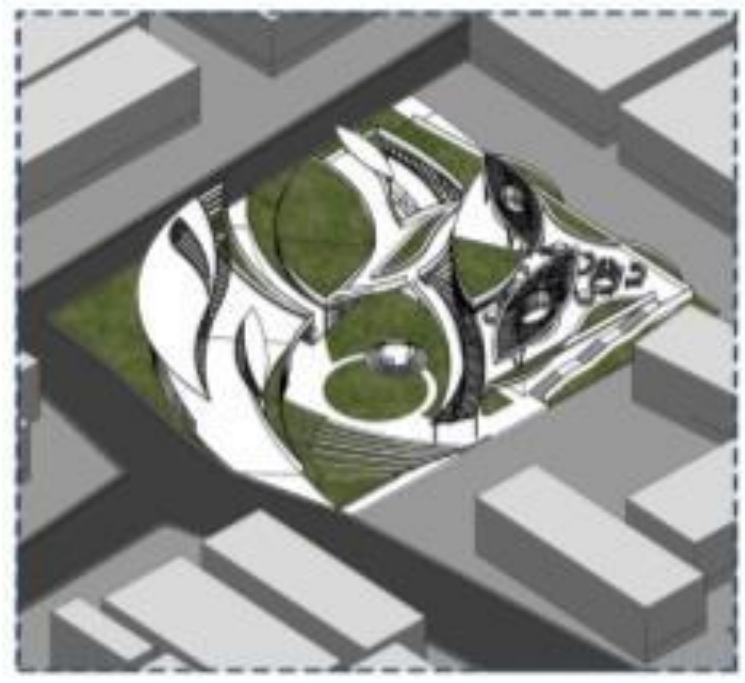

TROK IN DIEUAT DENCNN RAEA HLWU YANC BNWYK ACA ENCUNJUNC MAMTEN DaN JUCA BISA DIMDIKAN TEMPAT

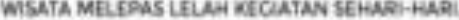

OENCAN BANVAKNYA AREA HIJAU JUCA BISA MENYARENC

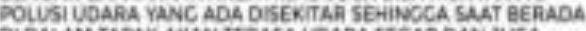
P.

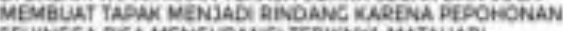
SEMINCCA BISA NENCLRANO TEDIKNVR MATAHADI

Gambar 5. Tahap Perancangan 1

Sumber. Dokumen Pribadi,2020 


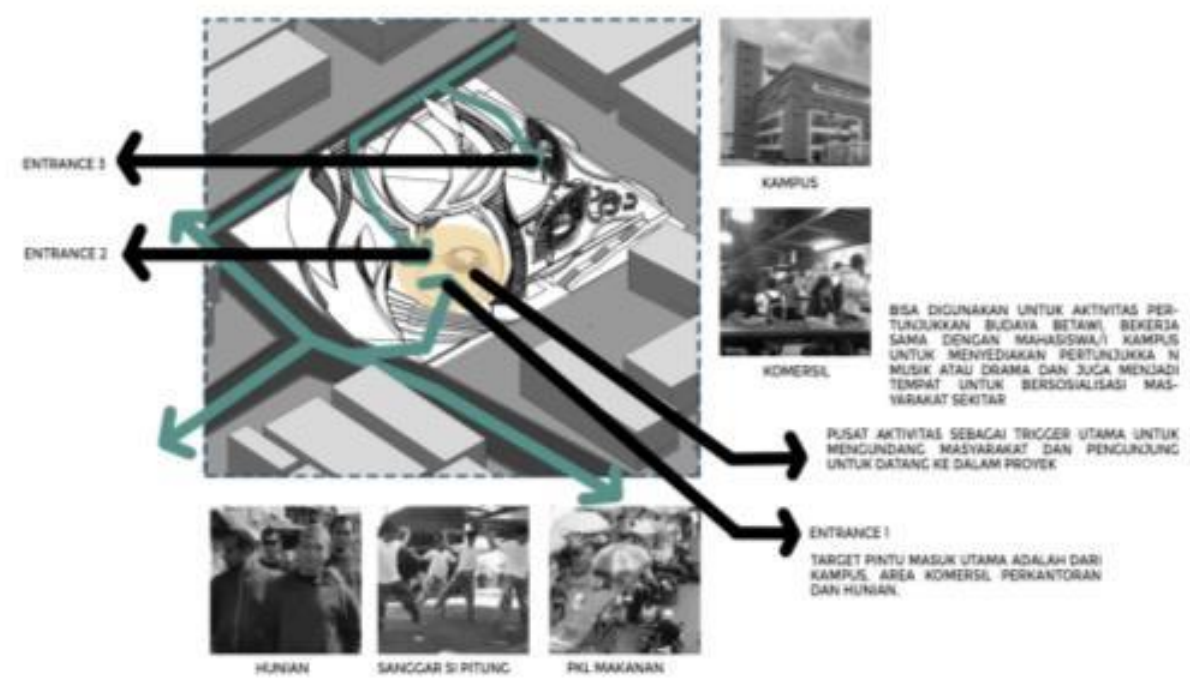

Gambar 6. Tahap Perancangan 2

Sumber. Dokumen Pribadi,2020

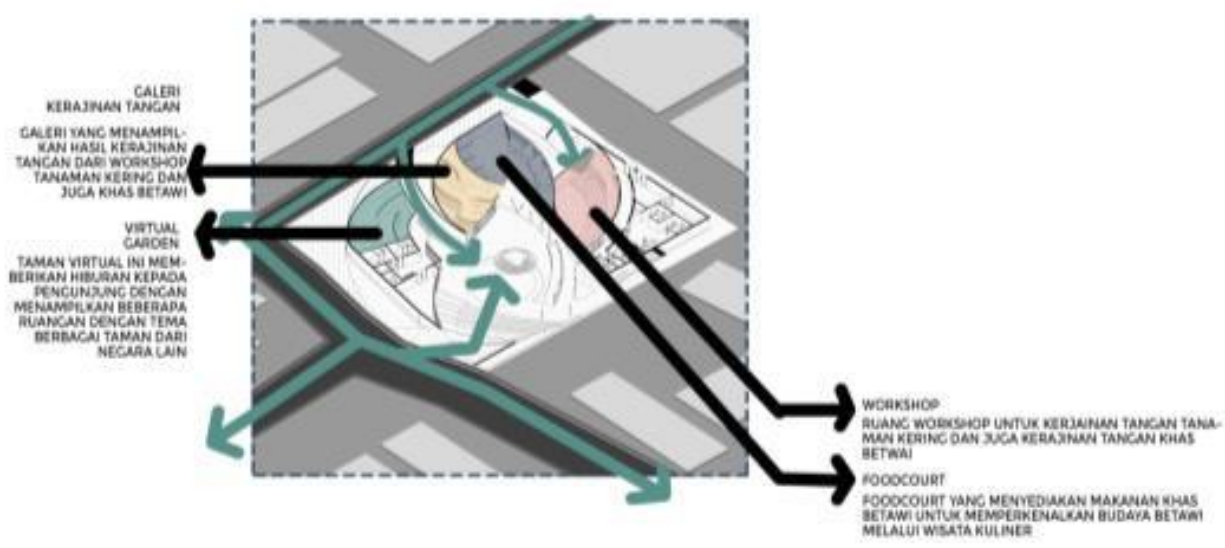

Gambar 7. Tahap Perancangan 3

Sumber. Dokumen Pribadi,2020

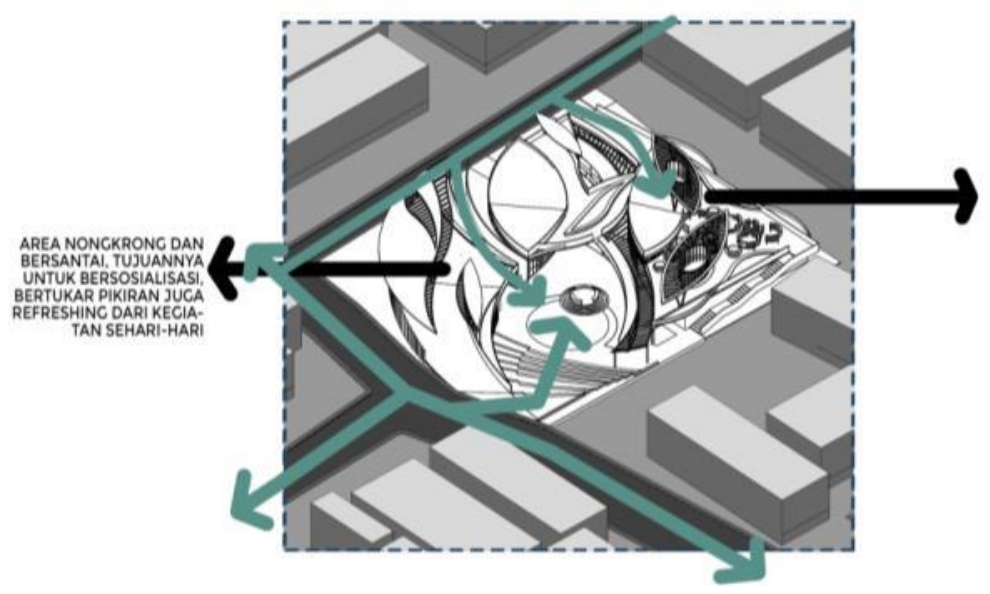

HIDROPONIC PAVILION

AREA MENANAM HIDROPONIC UNTUK MEMPERKEMENYEDIAKAN REKREASIYANC BERCUNA BACG NCUNJUNC

Gambar 8.Konsep Perancangan 4

Sumber. Dokumen Pribadi,2020

Berdasarkan analisis yang dilakukan, data-data observasi, analisis makro dan mikro, program kegiatan dan metode perancangan "everyday urbanism" yang sudah dilakukan. Demikian proses pemikiran konsep yang telah dilakukan. 


\section{Hasil}

Plataran Rempug Rawa Belong mengajak pembaca untuk bisa melihat potensi serta peluang di daerah Rawa Belong dari segi latar belakang budaya dan kekhasannya, komunitas dan user yang ada disana dan juga konsep yang ada. Proyek ini bertujuan sebagai titik temu (nodes) taman kota urban yang bertujuan untuk menjadi wadah belajar, rekreasi dan relaksasi.

Menyediakan third place bagi pedagang pasar tradisional, masyrakat sekitar, mahasisa/I dan semua kalangan masyarakat lain. Membangun interaksi sosial antar masyarakat satu dengan lainnya dan juga saling berbagi informasi, melakukan kegiatan yang berguna dikala bosan dan dapat mengurangi stres.

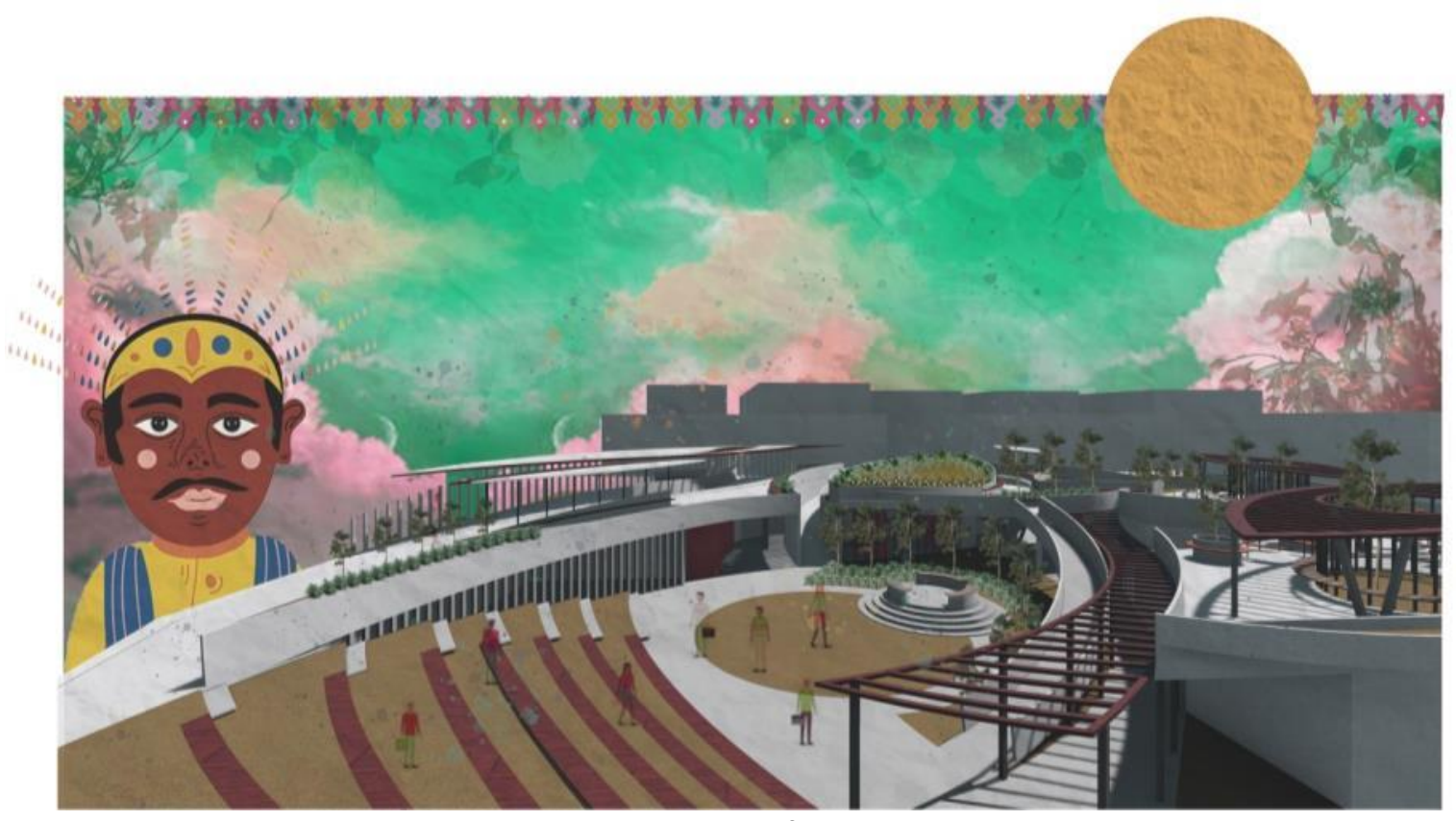

Gambar 9.Perspektif Eksterior

Sumber. Dokumen Pribadi,2020

\section{Ruang Komunal Rawa Belong}

Di Kawasan Rawa Belong minim adanya ruang komunal dan ruang hijau sebagai wadah rekreasi, sehingga proyek ini mengusulkan suatu ruang terbuka yang menjadi wadah tempat berkumpul semua komunitas dan masyarakat dan bisa dijadikan titik nodes Rawa Belong.

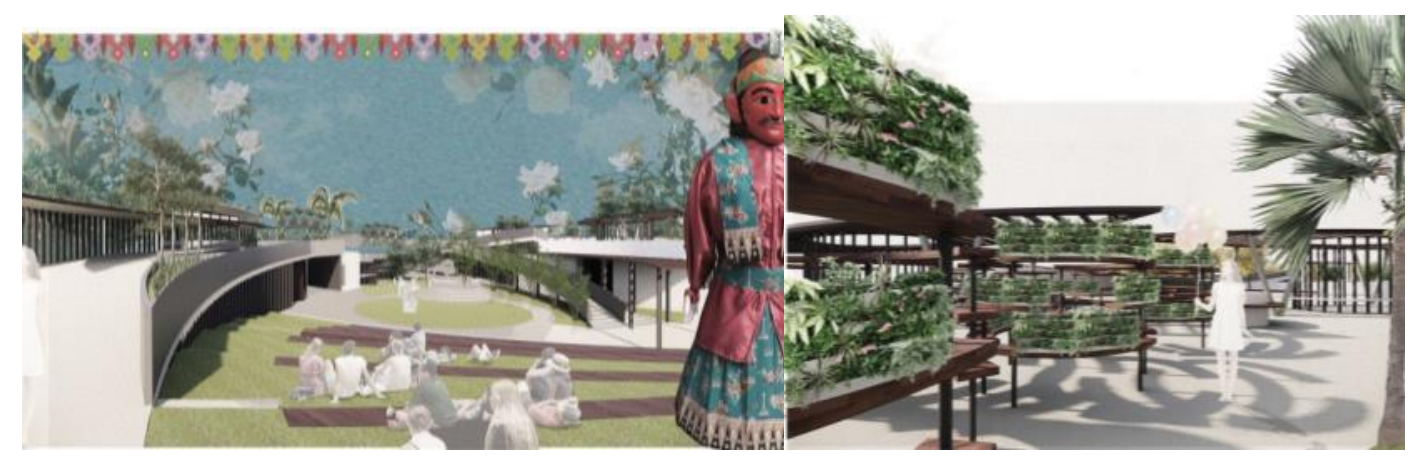

Gambar 10. Amphitheatre dan Paviliun Hidroponik Sumber. Dokumen Pribadi,2020

Area komunal Amphitheatre di desain sebagai trigger utama dari proyek, tujuannya untuk menarik pengunjung datang ke dalam proyek untuk sekedar menikmati suasana di dalam proyek juga bisa menyaksikkan pertunjukkan seni. Area ini merupakan ruang terbuka dimana 
masyarakat dapat berkumpul dan menikmati hijaunya pepohonan. Pencapaian akses menggunakan ramp untuk memudahkan semua pendatang, akses entrance didesain ada 3 untuk melingkupi 3 target yaitu masyarakat hunian, komersil dan perkantoran. Area komunal ini berusaha menciptakan suatu daerah komunal yang memiliki ke-7 aspek kriteria Third Place (Ray Oldenburg)
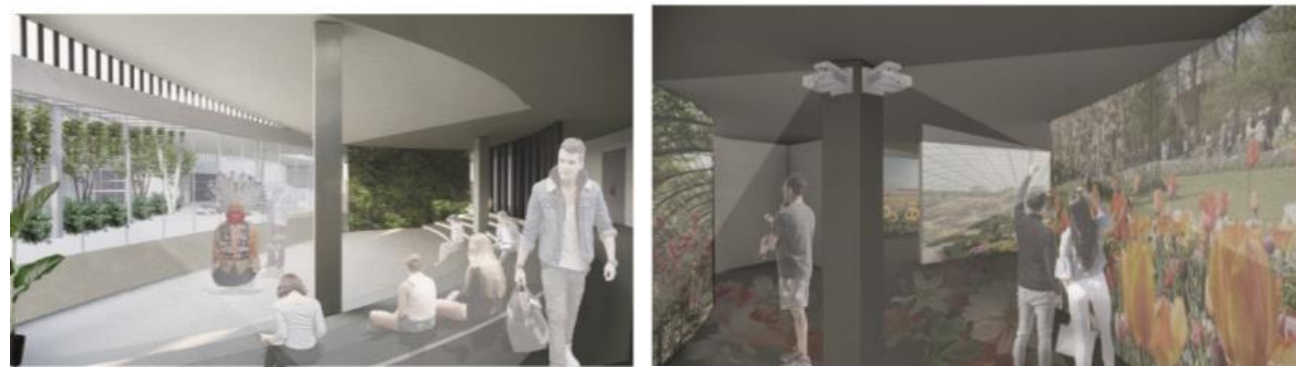

Gambar 11. Workshop dan Virtual Garden

Sumber. Dokumen Pribadi,2020

\section{Ruang Workshop dan Virtual Garden}

Ruang workshop ini menjadi wadah belajar dimana masyarakat dan komunitas-komunitas yang ada di sekitar tapak bisa belajar dan mendapat pengalaman baru. Adanya workshop ini juga bisa memberikan softskill baru untuk komunitas dan masyarakat untuk bisa menambah penghasilan mereka ataupun lainnya. Desain ruangan workshop dibuat terbuka agar pengunjung lain bisa melihat dari luar ruangan, ini dirancang untuk menarik orang ikut berpartisipasi dengan cara psikologis yaitu melihat langsung kegiatan yang ada didalamnya dan akan tergerak dan ingin ikut kegiatan tersebut. Selain itu juga ada virtual garden dimana di dalam ruangan ini pengunjung bisa menikmati pemandangan secara virtual taman-taman dan tumbuhan yang ada di luar negeri, selain itu juga bisa menjadikan spot instagramable untuk para anak muda jaman sekarang untuk di postingkan di sosial media. Karena kemajuan teknologi dan marketing saat ini, memudahkan proyek untuk bisa terkenal di kalangan anak muda dan orang-orang lainnya lewat sosial media.
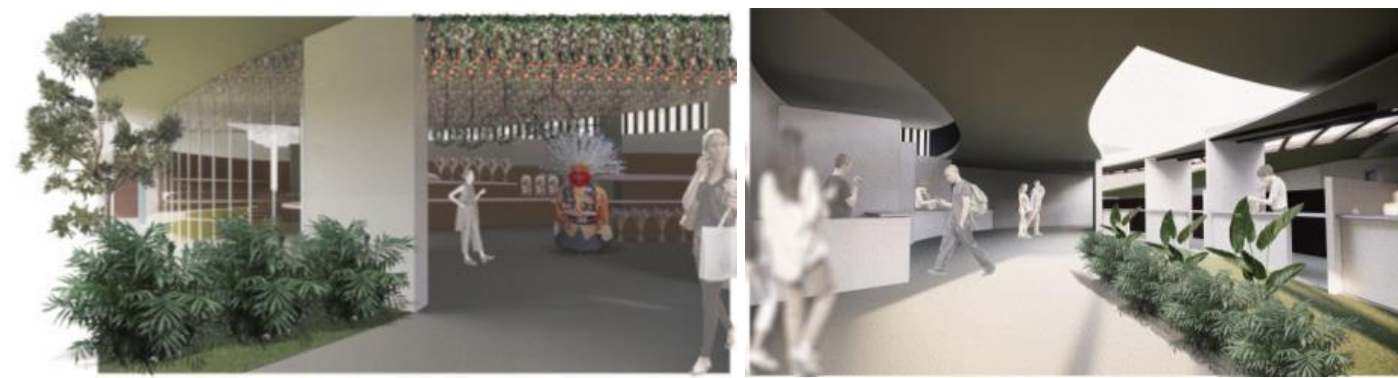

Gambar 12. Galeri Kerajinan Tangan dan Foodcourt Sumber. Dokumen Pribadi,2020

\section{Ruang Galeri Kerajinan Tangan dan Foodcourt}

Ruang galeri ini menjadi ruang pameran yang bertujuan untuk memamerkan hasil workshop yang dilakukan pengunjung juga ada beberapa dari kebudayaan Betawi untuk memperkenalkan sedikit tentang kebudayaan Betawi. Desain ruang Galeri ini dibuat dengan perpaduan tanaman hias yang digantung di plafon sehingga pengalaman yang didapat saat berada di dalam ruangan ini sangat kerasa. Pencahayaan juga sangat cukup karena ada skylight sehingga cahaya alami dapat masuk ke dalam ruangan. Ruang foodcourt ini untuk memperkenalkan budaya Betawi lewat kuliner, sehingga pengunjung dapat mencoba masakan dan jajanan khas Betawi. Desain foodcourt menjadi transisi untuk mengikat 2 ruangan yaitu ruang workshop dan galeri. 


\section{KESIMPULAN DAN SARAN \\ Kesimpulan}

Fasilitas ini didesain untuk menjawab solusi dari permasalahan di Kelurahan Rawa Belong yaitu menyediakan fasilitas dan wadah rekreasi dan relaksasi berupa taman kota dengan fasilitas lain didalamnya untuk memberi edukasi, hiburan, kreativitas dan sosialisasi bagi masyarakat dan pengunjung lain yang datang ke proyek. Selain itu fasilitas ini juga ikut menyediakan wadah untuk pengolahan sampah organik dan anorganik sehingga mengajak pengunjung dan masyarakat sekitar untuk berpartisipasi dalam menjaga lingkungan, hasil pengolahan sampah tersebut bisa menambah skill bagi komunitas dan pedagang tanaman hias sekitar untuk usaha kreatif kecil.

\section{Saran}

Diharapkan proyek ini dapat menjadi sebuah pusat relaksasi dan rekreasi bagi warga Jakarta yang setiap harinya menghadapi rutinitas dan keseharian yang padat. Kedepannya juga proyek ini bisa dikembangkan lagi bukan bukan hanya pengolahan sampah organic dan anorganik tapi juga bisa menggunakan bahan material lain. Juga menjadikan proyek ini sebagai taman kota dan nodes Kawasan Rawa Belong.

\section{REFERENSI}

Damayani, D.R.R. (2008). Gejala Ruang Ketiga (thirdspace) Di Kota Bandung: Paradoks Dalam Ruang Publik Urban Kontemporer. Disertasi Program Doktor. Institut Teknologi Bandung Holahan, C. J. (1982). Environmental Psychology. New York: Random House. Jormakka, K. (2008). Basics Design Methods. Berlin: Birkhauser Verlag AG Juniman, P. T. (2018). Studi: Milenial Lebih Stres di Kantor Dibanding Usia Lain. Diakses 17 Maret 2020, dari CNN Indonesia, https://www.cnnindonesia.com/gaya-hidup/studimilenial-lebih-stres-di-kantor-dibanding-usia-lain

Oldenburg, R. (1999). The Great Good Place. New York: Marlowe \& Company.

Putri, D., W. (2019). Ada Perubahan Cara Kerja Karyawan di Era Transformasi Digital. Diakses 19 Maret 2020, dari Republika, https://www.republika.co.id/berita/gayahidup/trend/17/04/11/oo8p99359-ada-perubahan-cara-kerja-karyawan-di-eratransformasi-digital

Rudi, A. (2016). Inilah Kawasan yang Telah Berubah dari RTH Jadi Perumahan dan Area Perdagangan. Dikutip 7 Maret 2020, dari Kompas.com

Trancik, R.(1986). Finding Lost Space: Theories Of Urban Spatial Design. New York: John Wiley \& Sons, Inc.

https://en.wikipedia.org/wiki/Third_place diakses pada tanggal 15 Febuari 2020

https://katadata.co.id/dinihariyanti/berita/5e9a55bb91512/apa-kata-startup-ekonomi-kreatiftentang-bekraf . diakses pada tanggal 8 Maret 2020

https://www.goodreads.com/book/show/4119.The_Great_Good_Place. pada tanggal 5 Febuari 2020. 